\title{
Infrared spectra of soil organic matter under a primary vegetation sequence
}

\author{
A. Nuzzo ${ }^{1^{*}}\left(\mathbb{D}\right.$, P. Buurman ${ }^{2}$, V. Cozzolino ${ }^{1,3}$, R. Spaccini ${ }^{1,3}$ and A. Piccolo ${ }^{1,3^{*}}$
}

\begin{abstract}
Background: We applied Fourier-Transformed Infrared Spectroscopy (FTIR) techniques in combination with selective humus extractions to investigate in situ the chemical features of organic matter in three soil profiles recently developed from Dutch sand dunes, under well-documented vegetation sequence and containing a relatively simple mineral-organic matter system. Water-soluble and alkaline-soluble extracts were also studied to match the changes of humus in the soil residues.

Results: Diffuse Reflectance Infrared Fourier Transform (DRIFT) and transmission spectra differed in resolution and sensitivity. DRIFT was superior in revealing structural information on the organic matter present in the soil samples whereas transmission spectra showed higher resolution for the bands of inorganic material at lower spectral frequencies. Differences between $\mathrm{H}$ and $\mathrm{B}$ horizons were due to the amount of hydrophilic organic acids, partly unsaturated, that were extracted by alkali. Extractable carboxylic acids and other hydrophilic compounds such as peptides and carbohydrates were larger in the less developed soils under pine and crowberry than in the more advanced profiles under beech. Humin residues from both $\mathrm{H}$ and $\mathrm{B}$ horizons retained unextractable aliphatic components and carboxylic groups involved in strong complexes with minerals, thereby confirming other findings that showed the largely aliphatic character of the unextractable humic fraction. Accumulation of poorly-soluble organic materials in these soils occur by protection from biodegradation due both to complexation with soil minerals and to a process by which apolar humic constituents form a separate hydrophobic phase where no biological activity can take place. Transport of poorly soluble compounds from $\mathrm{H}$ to $\mathrm{B}$ horizons, noticed especially in the more developed profiles, may have occurred through humic aggregates containing hydrophobic phases.
\end{abstract}

Conclusions: This work shows that the DRIFT technique in combination with soil chemical treatments can be suitably employed to investigate the changes of organic matter in whole soil samples and represents a valid tool to investigate the role of organic matter in soil profile development.

Keywords: Infrared spectroscopy, Soil, Humus, Podzolization, Beech, Crowberry

\section{Background}

The traditional approach to obtain physical-chemical information on the structure of soil organic matter is that of a quantitative extraction from soils [1]. However, critics against this approach has been growing over the years

\footnotetext{
*Correspondence: assunta.nuzzo@unina.it; riccardo.spaccini@unina.it

${ }^{1}$ Centro Interdipartimentale di Ricerca sulla Risonanza, Magnetica

Nucleare per I'Ambiente, I'Agro-Alimentare ed i Nuovi Materiali

(CERMANU), Università di Napoli, Federico II, Via Università 100

80055 Portici, Italy

Full list of author information is available at the end of the article
}

[2-4] because of the uncontrolled perturbation that a strong extractant such as an alkaline solution may cause to the structure of organic matter and its interactions with other soil components.

Few methods allow the study of soil organic matter without preliminary extraction that may alter its features to an unknown extent. These are mainly limited to solidstate ${ }^{13} \mathrm{C}$-NMR and Fourier-Transformed infrared spectroscopy (FT) as common transmission spectra by pellet technique or as DRIFT (Diffuse Reflectance Infrared Fourier Transform). Solid-state ${ }^{13} \mathrm{C}$-NMR is not adequate 
for routine studies because of the long acquisition time required when the whole soil sample is analyzed, its low band resolution, reduced sensitivity when abundant iron is present in soil, and the semi-quantitative results. Conversely, infrared techniques are rapid, require much less sample, and are very reproducible. Because of these advantages, infrared spectroscopy has been a traditional and powerful tool of soil organic matter chemistry even before the use of advanced FTIR instruments [1].

DRIFT spectroscopy has the same advantages of high reproducibility and semi-quantitativeness as the pellet technique, but it has the additional benefit that samples can be studied by simply mixing and grinding with a non-absorbing medium such as $\mathrm{KBr}$. This precludes the changes in organic matter characteristics that are induced when humic powders are pressed in $\mathrm{KBr}$ pellets [5]. Though DRIFT applications to soil organic matter studies are present in the literature either as spectra of humic substances extracted from soils [6-9] or of humus directly in soil samples, its direct application is yet to be generalized to study soil organic matter or soil genesis and development [10-12].

The objective of this work was to apply infrared techniques to study soil organic matter directly in soil samples that contain relatively simple mineral-organic matter systems. Soils of recent development, in which the organic matter chemistry is clearly linked to that of the standing vegetation should be ideal for this purpose, and the DRIFT technique allows the study of such organic matter without previous extraction. DRIFT measurements of bulk samples were compared with DRIFT and FTIR measurements of extracted materials, in order to assess the changes in the organic matter characteristics brought about by extractions.

\section{Soils, ecosystem, and profile development}

The samples selected for this study were taken from soils under a primary vegetation sequence on Dutch inland sand dunes. The dunes were active until the mid-1800s, after which both reforestation and gradual colonisation by natural vegetation have taken place. The parent material is quartz sand with a median size of about $150 \mu \mathrm{m}$. The quartz percentage lies around 95\%; admixed minerals were mainly feldspars and some opaque minerals. The clay contents are lower than $2 \%$ on a weight basis.

The vegetation development starts with algae, followed by widely-spaced tussocks of the grass Corynephorus canescens. In time, Corynephorus is accompanied by Spergula morrisonii. Both are succeeded by the moss Polytrichum piliferum. This vegetation development is accompanied by the formation of a very thin A horizon. In the natural sequence, widely spaced scots pine trees (Pinus silvestris) progressively establish themselves.
Under their protection, lichens such as Cladonia, and the mosses Dicranum scoparium and Hypnum cupressiforme begin to establish. They are gradually replaced by the grass Deschampsia flexuosa, which may constitute the dominant undergrowth for a long period. The soils develop thin humic A horizons. Deschampsia is replaced by Ericaceae, such as Vaccinium myrtillus, Empetrum nigrum and Vaccinium vitis-idaea (accompanied by the mosses Pleurozium schreberi and Leucobrium glaucum). Eventually, deciduous trees (Quercus robur, Fagus sylvatica) appear in the pine forest and the terminal stage is represented by the complete dominance of Fagus sylvatica (beech). Under planted pine forest, the vegetation sequence proceeds faster, because of higher litter production. Further details on this vegetation sequence may be found in the reports of Fanta [13] and Prach [14].

After the establishment of pine trees, the soil development proceeds in the direction of a podzol. Under pine and Ericaceae vegetation, the soil profile consists of an $\mathrm{L}$ (litter), an $\mathrm{F}$ (fragmentation) and an $\mathrm{H}$ (humification) layer which overlie the mineral soil. The $\mathrm{L}$ is usually thin, except in the case of spontaneously established pine trees without undergrowth, where it may be several $\mathrm{cm}$ thick. The F horizon can be as thick as $15 \mathrm{~cm}$, and the black, strongly humified $\mathrm{H}$ horizon may reach a thickness of $3 \mathrm{~cm}$. A definite $\mathrm{E}$ (eluvial) horizon, about $10 \mathrm{~cm}$ thick, develops under the organic horizons, while below this horizon humus accumulates in a Bh (illuvial) horizon. Biological homogenization in the mineral soil is virtually zero and therefore the accumulated humus in the Bh horizon must occur by downward transport of either dissolved organic matter or particulate material, or by accumulation of organic material from decayed roots.

The described soil system represents a unique development sequence from which important information may be obtained on the organic matter differentiation depending on vegetation sequence and soil depth. The soils reported in this paper were from pine forest with Empetrum undergrowth (profile I), and beech forest with (profile II) and without (profile III) remnants of $\mathrm{Vac}$ cinium undergrowth. All these soils have (L)-F-H-E-B horizon sequences. Table 1 shows that the $\mathrm{H}$ horizon had invariably the largest percent $C$ in all profiles and that carbon decreased to much lower values in $\mathrm{E}$ and $\mathrm{B}$ horizons and was hardly detectable in the $\mathrm{C}$ horizon. Table 1 also reveals that percent $\mathrm{C}$ of the $\mathrm{H}$-horizon in profile III was significantly smaller than in profile II, thereby suggesting that the presence of undergrowth vegetation was much more effective than beech litter per se in forming this horizon. The larger $\mathrm{C}$ content in profile II should be attributed to less admixture of sand. On the other hand, the general increase of $\mathrm{pH}$ with soil depth indicates that organic acidic compounds are relevant in the $\mathrm{H}$ horizons 
Table $1 \mathrm{C}, \mathrm{N}, \mathrm{H}, \mathrm{C} / \mathrm{N}$ and $\mathrm{C} / \mathrm{H}$ ratios, and $\mathrm{pH}$ of different horizons in the soil profiles of this study

\begin{tabular}{|c|c|c|c|c|c|c|c|}
\hline Horizon & $\% \mathrm{C}$ & $\% \mathrm{~N}$ & $\% \mathrm{H}$ & $\mathrm{C} / \mathrm{N}$ & $\mathrm{C} / \mathrm{H}$ & $\mathrm{pH}(\mathrm{H} 20)$ & $\mathrm{PH}(\mathrm{KCl})$ \\
\hline & Profil & & & & & & \\
\hline $\mathrm{H}$ & 35.3 & 1.12 & 3.8 & 31.5 & 9.3 & 3.5 & 2.5 \\
\hline E & 0.9 & 0.02 & 0.05 & 45.0 & 18.0 & 3.9 & 3.4 \\
\hline B & 0.2 & 0.02 & 0.04 & 10.0 & 5.0 & 3.7 & 3.5 \\
\hline \multirow[t]{2}{*}{ C } & 0.2 & 0.01 & 0.03 & 20.0 & 6.7 & 4.2 & 4.5 \\
\hline & Profil & & & & & & \\
\hline $\mathrm{H}$ & 41.0 & 1.42 & 5.05 & 28.9 & 8.1 & 3.5 & 2.5 \\
\hline E & 0.6 & 0.02 & 0.04 & 30.0 & 15.0 & 3.8 & 3.4 \\
\hline B & 0.5 & 0.02 & 0.01 & 25.0 & 50.0 & 3.8 & 3.7 \\
\hline \multirow[t]{2}{*}{ C } & 0.1 & 0.01 & 0.01 & 10.0 & 10.0 & 4.4 & 4.7 \\
\hline & Profil & & & & & & \\
\hline $\mathrm{H}$ & 22.1 & 0.93 & 2.81 & 23.8 & 7.9 & 3.7 & 2.6 \\
\hline E & 0.7 & 0.04 & 0.04 & 17.5 & 17.5 & 3.8 & 3.4 \\
\hline B & 0.8 & 0.04 & 0.08 & 20.0 & 10.0 & 3.7 & 3.4 \\
\hline C & 0.2 & 0.01 & 0.01 & 20.0 & 20.0 & 4.3 & 4.7 \\
\hline
\end{tabular}

and are partially leached down to the lower B horizons. An investigation on the organic matter features of the $\mathrm{H}$ and $B$ horizons of these three profiles may hence provide some useful information to explain the process of organic matter translocation from surface to lower horizons.

\section{Profile descriptions}

Soil profiles are described hereafter by using the terminology of Green et al. [15] for organic horizons, and that of FAO [16] for the mineral soil profile. Soil colours were described with Munsell [17].

\section{Profile I}

Site: top of sand dune, approximately $5 \mathrm{~m}$ above surroundings.

Vegetation: Pinus sylvestris, planted, 90-105 years old; some small Quercus pubescens.

Undergrowth of Empetrum nigrum (crowberry) on the site, with minor amounts of the moss

\section{Pleurozium schreberi.}

Profile:

\begin{tabular}{lll}
\hline Horizon & $\begin{array}{l}\text { Depth/ } \\
\text { thickness } \\
(\mathbf{c m})\end{array}$ & Description \\
\hline $\mathrm{L}$ & $0-2$ & $\begin{array}{l}\text { Consisting of pine needles and fragments of } \\
\text { Empetrum branches } \\
\text { Pine needle fragments and Empetrum frag- } \\
\text { ments, with abundant roots of Empetrum }\end{array}$ \\
$\mathrm{F} 2$ & 2 & $\begin{array}{r}\text { Partly humified material and abundant roots of } \\
\text { Empetrum }\end{array}$ \\
$\mathrm{FH}$ & 3 & $\begin{array}{r}\text { Few recognizable roots and back remnants, } \\
\text { largely humified material }\end{array}$ \\
\hline
\end{tabular}

\begin{tabular}{|c|c|c|}
\hline Horizon & $\begin{array}{l}\text { Depth/ } \\
\text { thickness } \\
(\mathrm{cm})\end{array}$ & Description \\
\hline$\overline{\mathrm{H}}$ & $1-2$ & $\begin{array}{l}\text { Very dark brown (10YR 2/2) smeary, fully decom- } \\
\text { posed organic material. Sharp transition to the } \\
\text { mineral horizons }\end{array}$ \\
\hline E & $0-2$ & $\begin{array}{l}\text { Light grey/N7//) sand without roots and with little } \\
\text { organic matter sharp transition to }\end{array}$ \\
\hline $\mathrm{Bh}$ & $2-8$ & $\begin{array}{l}\text { Pale brown (10 YR 6/3) sand with dine roots; } \\
\text { structureless; gradual transition to }\end{array}$ \\
\hline $\mathrm{BC}$ & $8-15$ & $\begin{array}{l}\text { Light grey (10 YR } 7 / 2) \text { sand without roots, struc- } \\
\text { tureless; gradual transition to:C }\end{array}$ \\
\hline C & $15+$ & White (2.5 Y 8/2) sand \\
\hline
\end{tabular}

Profile II

Site: top of sand dune. approximately 6 metres above surroundings.

Vegetation: only Fagus sylvatica (beech) on the site. In the surroundings Pinus sylvestris. up to 140 years old and full-grown Quercus robur, sparse Vaccinium m_vrtillus undergrowth.

Profile:

\begin{tabular}{|c|c|c|}
\hline Horizon & Depth/thickness & Description \\
\hline L & $5 \mathrm{~cm}$ & $\begin{array}{l}\text { Freshly fallen beech leaves with some pine } \\
\text { needles }\end{array}$ \\
\hline $\mathrm{Fl}$ & $4 \mathrm{~cm}$ & $\begin{array}{l}\text { Fragmented beech leaves brown (I0 YR } \\
5 / 3 \text { ) }\end{array}$ \\
\hline F2 & $1 \mathrm{~cm}$ & $\begin{array}{l}\text { Dark greyish brown (10 YR 4/3) more } \\
\text { decomposed leaves }\end{array}$ \\
\hline $\mathrm{H}$ & $1-5 \mathrm{~cm}$ & $\begin{array}{l}\text { Very dark brown (10 YR 2/2) humified } \\
\text { material, no roots, sharp. Transition to } \\
\text { mineral profile }\end{array}$ \\
\hline
\end{tabular}




\begin{tabular}{|c|c|c|}
\hline Horizon & Depth/thickness & Description \\
\hline $\bar{A}$ & $0-2 \mathrm{~cm}$ & $\begin{array}{l}\text { Irregular, black (10 YR 2/1) organic-rich } \\
\text { sand with common fine beech roots. } \\
\text { Sharp transition to E horizon }\end{array}$ \\
\hline E & $2-8 / 11 \mathrm{~cm}$ & $\begin{array}{l}\text { Grey }(10 \text { YR } 5 / 1) \text { sand with locally thin } \\
\text { bands of } \mathrm{H} \text {-material, common fine } \\
\text { beech roots. Wavy but sharp transition } \\
\text { to Bh }\end{array}$ \\
\hline $\mathrm{Bh}$ & $8 / 11-13 / 22$ & $\begin{array}{l}\text { Yellowish brown (I0 YR 5/4) humus sand, } \\
\text { structureless. Few fine roots. Diffuse } \\
\text { boundary to C }\end{array}$ \\
\hline C & $22+\mathrm{cm}$ & White sand \\
\hline
\end{tabular}

\section{Profile III}

Site: Foot of $8 \mathrm{~m}$ high sand dune.

Vegetation: Exclusively beech of unknown age (Fagus sylvatica), no undergrowth.

Profile:

\begin{tabular}{|c|c|c|}
\hline Horizon & $\begin{array}{l}\text { Depth/ } \\
\text { thickness } \\
\text { (cm) }\end{array}$ & Description \\
\hline$L$ & $2-3$ & Freshly fallen beech leaves \\
\hline $\mathrm{F}$ & 3 & $\begin{array}{l}\text { Fragmented leaves, fruits } \\
\text { and twigs. Root mat with } \\
\text { abrupt transition to: }\end{array}$ \\
\hline $\mathrm{FH}$ & 1 & $\begin{array}{l}\text { Dark greyish brown (10 YR } \\
\text { 4/2) strongly humificd litter } \\
\text { with remnants of twigs }\end{array}$ \\
\hline $\mathrm{H}$ & $0-2$ & $\begin{array}{l}\text { Intermittent, black (10 YR 2/1) } \\
\text { humified material Some } \\
\text { admixed sand, few roots. } \\
\text { Abrupt transition to: }\end{array}$ \\
\hline$E$ & $1-4$ & $\begin{array}{l}\text { Light grey to grey (10 YR 7/1- } \\
5 / 1 \text { ) sand with few roots. } \\
\text { Slightly mottled appear- } \\
\text { ance. Sharp and irregular } \\
\text { boundary to }\end{array}$ \\
\hline $\mathrm{Bh}$ & $2-7$ & $\begin{array}{l}\text { Dark brown (10 YR 4/3) } \\
\text { humus sand. Few medium } \\
\text { roots. Clear and wavy } \\
\text { transition to: }\end{array}$ \\
\hline $\mathrm{BC}$ & $5-10$ & $\begin{array}{l}\text { Pale yellow }(2.5 \text { Y } 7 / 4) \text { sand } \\
\text { with few medium iron } \\
\text { mottles ( } 10 \text { YR } 6 / 6) \text { and } \\
\text { inclusions of } C \text { material. } \\
\text { Slightly darker in rooted } \\
\text { parts. Gradual transition to }\end{array}$ \\
\hline C & $15 / 18+$ & $\begin{array}{l}\text { White sand, few roots. rem- } \\
\text { nants of stratification }\end{array}$ \\
\hline
\end{tabular}

\section{Materials and methods}

\section{Humus extracts}

Water-extract: Field moist samples were shaken with distilled water (solid:solution ratio of 1:4) during 16-20 h. The solution was decanted and centrifuged for $1 \mathrm{~h}$ at
$8500 g$. The residue was shaken again with water (1:2), decanted, and the solution centrifuged. The two solutions were then combined, filtered over an $0.45 \mu \mathrm{m}$ filter, and freeze-dried. The yield was $0.1-0.5 \%$ of the total organic matter content

Alkali-extract: Field moist samples were shaken with $0.5 \mathrm{M} \mathrm{NaOH}$ (solid:solution ratio of 1:20) for $24 \mathrm{~h}$ under nitrogen. The solution was decanted and centrifuged for 1 hour at $8500 \mathrm{~g}$. The residue was shaken with distilled water for $2 \mathrm{~h}$. After decanting and centrifuging, both solutions were combined and filtered over a $0.45 \mu \mathrm{m}$ filter. The filtered solution was dialysed against distilled water and freeze dried. Yields were $45-55 \%$ and $85-90 \%$ of original soil organic matter for the $\mathrm{H}$ and $\mathrm{B}$ horizons, respectively.

\section{Humin residue}

The soil residue after alkaline extraction was decanted to remove sand particles. Thereafter the non-sand fraction was washed various times with distilled water and centrifuged until the supernatant had a $\mathrm{pH}$ of $7-8$. The residue was then freeze dried. The residue constituted $45-55 \%$, and $10-15 \%$ of original soil organic matter for the $\mathrm{H}$ and $B$ horizons, respectively.

\section{Analyses}

Elemental carbon, hydrogen and nitrogen of the whole soil samples, of humus extracts and of humin soil residues were obtained by a Fyson elemental analyzer, whereas their ash content was evaluated by differential thermal gravimetry.

\section{Infrared spectroscopy}

Transmission spectroscopy (FTIR): $1 \mathrm{mg}$ of sample was mixed with $300 \mathrm{mg}$ of $\mathrm{KBr}$ and ground in a Whig-l-Bug agate micromill. After vacuum suction for $15 \mathrm{~min}$, the fine mixed powder was pressed into a pellet under a pressure of 10 tons $/ \mathrm{cm}^{2}$ for $15 \mathrm{~min}$. The pellet was dried out overnight at $60{ }^{\circ} \mathrm{C}$ to reduce interferences from water bands [5], and the relative spectrum was obtained by a Perkin-Elmer 1720X FTIR spectrometer. Resolution was set at $2 \mathrm{~cm}^{-1}$, while the gain was kept at 1 . Fifty scans were run for each pellet and 10-20 for the background spectrum.

DRIFT: $15 \mathrm{mg}$ of sample were mixed with $200 \mathrm{mg}$ of $\mathrm{KBr}$ and ground in the Whig-l-Bug agate micromill. The samples were placed in a Perkin-Elmer Diffuse Reflectance accessory allocated in the instrument's compartment where a dessiccant $\left(\mathrm{P}_{2} \mathrm{O}_{5}\right)$ ensured a water-free atmosphere. After maximization of the reflected energy, spectra were measured by the FTIR spectrometer. Gain was set at 8 and the resolution was $4 \mathrm{~cm}^{-1}$. 200 scans 
were accumulated for each sample and 50 for the interferogram of background correction. Reflectance spectra were transformed to Kubelka-Munk (KM) units by the instrument's software.

\section{Results and discussion \\ Characteristics of samples}

The elemental $\mathrm{C}$ and $\mathrm{N}$ composition, and the ash content of whole soil samples, of the relative water- and alkali-extracts, and of the humin residue left in the soils are shown in Table 2. A general increase in $\mathrm{C}$ content is observed in all profiles when passing from the whole soil sample (total soil) to the water- and alkali-extracts. C content in the humin residue after $\mathrm{NaOH}$ extraction was larger than in the original soil sample before extraction. This is due to the carbon concentration enhancement that occurred during alkali extraction because of the easy decanting of sand and most of the silt (about 99\% of the soils' mineral matter) (see "Materials and methods" section). The ash content of the final humin sample consists mainly of fine silt and clay.

The more advanced development of profiles II and III under beech forest with respect to profile I under pine forest, is reflected by the enhanced humification of the horizons in the former profiles. Each residue and humus extract of both $\mathrm{H}$ and $\mathrm{B}$ horizons of profile I revealed a smaller organic carbon content than that of the comparable horizon of profiles II and III. The presence of more biologically stable humus in profiles II and III, as compared to profile $\mathrm{I}$, is confirmed by the decreasing trend shown by the $\mathrm{C} / \mathrm{N}$ (ratio of the carbon mass to the nitrogen mass) values of each horizon's fraction when passing from the latter to the former profiles, except for total soil and humin of B-horizon, probably because of the different quality of soil organic matter [18].

\section{Comparison of DRIFT and transmission spectra}

We obtained both DRIFT and Transmission (FTIR) spectra of the whole soil samples (Total) and of the soil residues (Humin) after $\mathrm{NaOH}$ extractions for both $\mathrm{H}$ and B horizons of the three profiles. Differences between DRIFT and FTIR spectra were consistent in the three profiles. As for profile II, FTIR (Fig. 1) and DRIFT (Fig. 2) spectra for both Total and Humin samples of $\mathrm{H}$-horizon and for the Humin residue of B-horizon are reported.

In the $3700-3000 \mathrm{~cm}^{-1}$ interval, DRIFT spectra (Fig. 2) appear more resolved than the FTIR spectra (Fig. 1). Some resolved absorption bands can be identified in DRIFT spectra, whereas FTIR spectra did not show more than a broad strong band centered near $3450 \mathrm{~cm}^{-1}$. This difference may be due to the less sensitivity to water absorption of DRIFT in respect to FTIR. In the latter technique, although the $\mathrm{KBr}$ pellets had been dried overnight at $60{ }^{\circ} \mathrm{C}[5]$, the interference due to the $\mathrm{O}-\mathrm{H}$ stretchings of water molecules may still mask the bands that are, instead, visible in DRIFT spectra. Another possible explanation is that DRIFT samples were not subjected to the high pressure used to make pellets for Transmission analysis, and, being DRIFT a reflectance measurement, a large resolution was possible for this technique [12].

At smaller wave numbers $\left(3000-2500 \mathrm{~cm}^{-1}\right)$, DRIFT spectra of all profiles showed an increase in the aliphatic region $\left(\mathrm{C}-\mathrm{H}\right.$ stretchings of $\mathrm{CH}_{2}$ groups at 2920 and $2850 \mathrm{~cm}^{-1}$ ) when going from H-Total to $\mathrm{H}$-Humin samples (Fig. 2). This band's enhancement indicates that compounds rich in aliphatic carbon were not removed by the $\mathrm{NaOH}$ extraction. As expected, the alkaline treatment must hence selectively extract hydrophilic humus components which are more soluble in aqueous alkaline solutions rather than hydrophobic aliphatic constituents. The stability of aliphatic groups in the soil organic matter structures versus alkaline extractions is confirmed by the intense aliphatic bands that are still present in the DRIFT spectrum of B-Humin (Fig. 2). FTIR spectra (Fig. 1) show the same trend for the aliphatic bands, although the evaluation of changes is complicated by the phase alteration of the spectrum due to the different light scattering above $3500 \mathrm{~cm}^{-1}$ observed for H-Total and H-Humin.

In DRIFT spectra, the absorption around 2600$2500 \mathrm{~cm}^{-1}$, that is commonly attributed to the hydrogenbonded $\mathrm{COOH}$ dimers $[6,19]$, decreased consistently from $\mathrm{H}$-Total to $\mathrm{H}$-Humin (Fig. 2), thereby indicating either a dissociation of carboxyl groups at the $\mathrm{pH}$ of the residue (between $\mathrm{pH} 7$ and 8 ) and/or their removal from the soil samples. In FTIR spectra, instead, the variable quality of pellets induced a variable light scattering in the higher frequencies and prevented the recognition of such a change. This difference emphasizes the more reproducible quality of DRIFT spectra as compared to those of pellets. Moreover, DRIFT spectra appear more sensitive than FTIR in the region between 2500 and $1900 \mathrm{~cm}^{-1}$. Various absorption bands, which are attributable to quartz and silicate harmonic reflections (overtones as by [20]), were visible in this interval by DRIFT but were unclear by FTIR.

Similar features are shown by DRIFT and FTIR spectra in the $1800-1700 \mathrm{~cm}^{-1}$ region, where the broad absorption between 1730 and $1700 \mathrm{~cm}^{-1}$ was distinctly reduced after $\mathrm{NaOH}$ extraction when passing from $\mathrm{H}$-Total to H-Humin. Only a sharp peak at about $1720 \mathrm{~cm}^{-1}$ (1733 $\mathrm{cm}^{-1}$ for FTIR) remained visible in the H-humin residue. The reduction of the $\mathrm{C}=\mathrm{O}$ stretching band of humic carboxyl functions which absorb between 1705 and $1720 \mathrm{~cm}^{-1}$ [19] was mostly due to the dissociation 
Table 2 Percent of ash, $\mathrm{C}, \mathrm{N}$, and $\mathrm{C} / \mathrm{N}$ ratio, of humic extracts and soil residues

\begin{tabular}{|c|c|c|c|c|c|c|}
\hline Profile & Horizon & Sample & Ash & $\mathrm{C}$ & $\mathrm{N}$ & $\mathrm{C} / \mathrm{N}$ \\
\hline \multirow[t]{7}{*}{ I } & $\mathrm{H}$ & Total soil ${ }^{a}$ & 37.9 & 35.3 & 1.12 & 31.5 \\
\hline & $\mathrm{H}$ & Water-extract ${ }^{b}$ & 7.4 & 45.3 & 1.92 & 23.6 \\
\hline & $\mathrm{H}$ & Alkali-extract ${ }^{c}$ & 4.9 & 50.4 & 1.55 & 32.5 \\
\hline & $\mathrm{H}$ & Humin ${ }^{d}$ & 11.7 & 49.0 & 1.00 & 49.0 \\
\hline & B & Total soil & 99.2 & 0.2 & 0.02 & 10.0 \\
\hline & B & Alkali-extract & 11.5 & 41.5 & 1.63 & 25.5 \\
\hline & B & Humin & 70.2 & 11.1 & 0.32 & 34.7 \\
\hline \multirow[t]{7}{*}{$\|$} & $\mathrm{H}$ & Total soil & 22.3 & 41.0 & 1.42 & 28.9 \\
\hline & $\mathrm{H}$ & Water-extract & 7.0 & 44.6 & 2.15 & 20.7 \\
\hline & $\mathrm{H}$ & Alkali-extract & 5.4 & 51.7 & 1.95 & 26.5 \\
\hline & $\mathrm{H}$ & Humin & 12.9 & 49.0 & 1.32 & 37.1 \\
\hline & B & Total-soil & 99.0 & 0.5 & 0.02 & 25.0 \\
\hline & B & Alkali-extract & 12.5 & 41.4 & 1.67 & 24.8 \\
\hline & B & Humin & 67.9 & 16.4 & 0.52 & 31.5 \\
\hline \multirow[t]{7}{*}{ III } & $\mathrm{H}$ & Total-soil & 58.5 & 22.1 & 0.93 & 23.8 \\
\hline & $\mathrm{H}$ & Water-extract & 9.3 & 44.3 & 2.45 & 18.4 \\
\hline & $\mathrm{H}$ & Alkali-extract & 4.7 & 51.6 & 2.38 & 21.7 \\
\hline & $\mathrm{H}$ & Humin & 16.0 & 49.5 & 1.60 & 30.9 \\
\hline & B & Total soil & 98.4 & 0.8 & 0.04 & 20.0 \\
\hline & B & Alkali-extract & 10.2 & 43.9 & 2.18 & 20.1 \\
\hline & $B$ & Humin & 71.4 & 19.7 & 0.56 & 35.2 \\
\hline
\end{tabular}

a Whole soil sample

b Water-extract from the soil sample

c Alkali-extract from the soil sample

d Soil residue (Humin) after alkali extraction

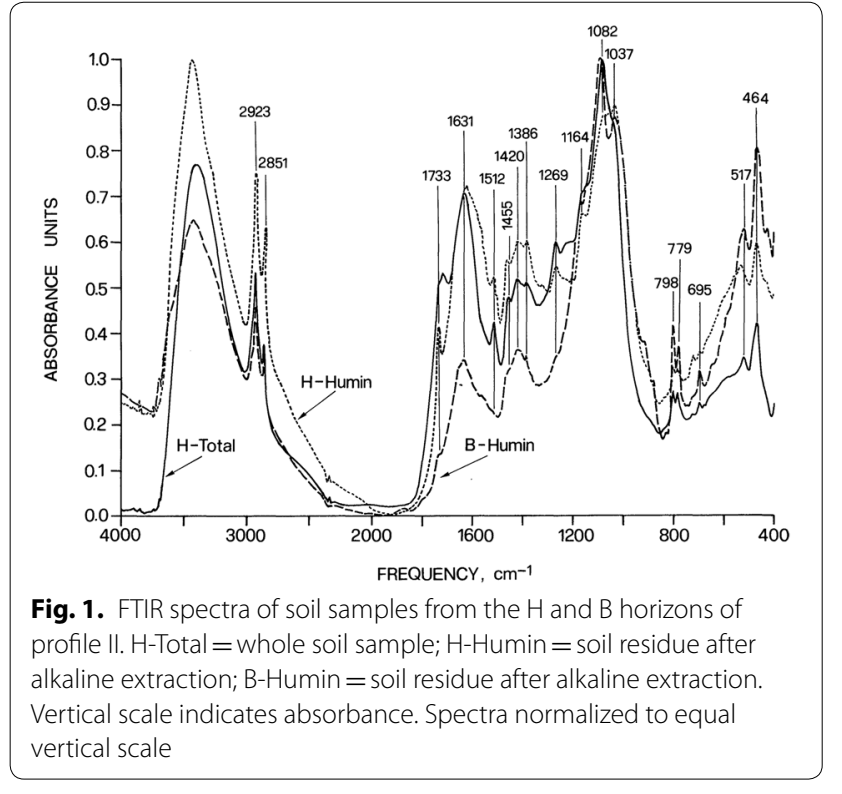

of $\mathrm{COOH}$ groups and produced a concomitant unmasking of other absorptions at about $1730-1720 \mathrm{~cm}^{-1}$. These bands may be attributed to carbonyl groups in conjugated

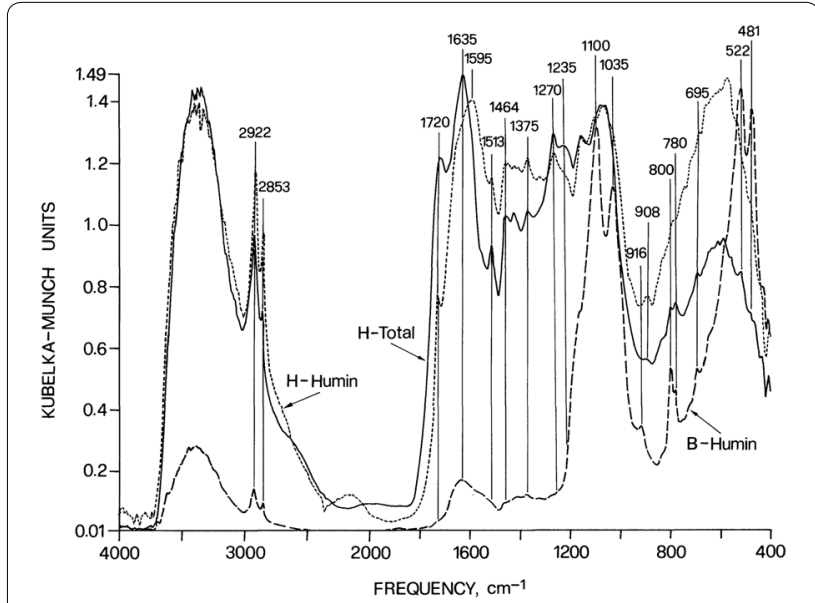

Fig. 2 DRIFT spectra of soil samples from the $H$ and $B$ horizons of profile II. H-Total = whole soil sample; $\mathrm{H}$-Humin = soil residue after alkaline extraction; B-Humin = soil residue after alkaline extraction. Vertical scale in Kubelka-Munk units. Spectra normalized to equal vertical scale

or heterocyclic moieties which are reported to absorb at slightly higher frequencies than those of carboxyl groups $[19,21,22]$. 
DRIFT and FTIR spectra diverged in the 1700$1550 \mathrm{~cm}^{-1}$ region. DRIFT spectra (Fig. 2) showed a distinct decrease of the $1620-1635 \mathrm{~cm}^{-1}$ band when passing from $\mathrm{H}$-Total to $\mathrm{H}$-Humin, with a parallel increase of the $1600-1520$ and $1450-1350 \mathrm{~cm}^{-1}$ regions. These changes can be explained with both the formation of sodium salts of acidic functions due to the $\mathrm{NaOH}$ treatment and the loss of organic material during the extraction. In fact, the absorption in the region around $1630 \mathrm{~cm}^{-1}$ is commonly attributed to double bond stretching in conjugated or non-conjugated unsaturated compounds [6-8, $21,22]$ and the decrease of such band seems then to suggest that soil lost some unsaturated compounds. If this observation is combined with the noticed decrease of carboxyl groups at around $1710 \mathrm{~cm}^{-1}$, it can be inferred that the material passed in the alkaline extract was rich in organic acids containing unsaturated or phenyl groups. By the same reasoning, the formation of carboxylate groups from unextracted carboxyls is responsible, in the $\mathrm{H}$-Humin residue, for enhanced absorptions in the 1600 $1520 \mathrm{~cm}^{-1}$ region (carboxylate asymmetric stretching) and around $1400 \mathrm{~cm}^{-1}$ (carboxylate symmetric stretching). In fact, the increase of carboxylate groups due to the alkaline treatment of soil may be the cause of the slight enhancement of the $1375 \mathrm{~cm}^{-1}$ band (carboxylate symmetric stretching) that was also visible in the DRIFT spectrum of $\mathrm{H}$-Humin. These changes are less evident in FTIR spectra (Fig. 1), except for the absorption increases in the $1580-1551 \mathrm{~cm}^{-1}$ interval and at around $1400 \mathrm{~cm}^{-1}$, which are also attributable to carboxylate bands. In both FTIR and DRIFT spectra, the B-Humin samples did not provide many details in this region but appear to behave similarly to the $\mathrm{H}$-Total samples.

Both Figs. 1 and 2 showed a decrease of the 1515$1510 \mathrm{~cm}^{-1}$ region when going from H-Total to H-Humin. There is a large consensus in attributing this absorption to the Amide-II bands of peptides and proteins $[6,8,12$, $21,22]$. The reduction of this band hence indicates that the most hydrophilic proteinaceous material must have been transferred into the extracting alkaline solution. The Amide-II band was hardly visible in the B-Humin spectra of both FTIR and DRIFT, thereby suggesting either a probable much lower content of proteinaceous material in this horizon or, but less likely, a more efficient solubilization of this fraction into the alkaline extractant.

Some absorptions in the $1500-1350 \mathrm{~cm}^{-1}$ interva1 may be attributed to the deformations of $\mathrm{CH}_{2}$ and $\mathrm{CH}_{3}$ groups [21]. This region appears much more resolved in DRIFT spectra where some distinct bands showed an increase when passing from $\mathrm{H}$-Total to $\mathrm{H}$-Humin samples. This relates well with the enhanced bands of aliphatic groups observed at 2920 and $2850 \mathrm{~cm}^{-1}$. Although a similar trend may be guessed from the FTIR spectra, the evaluation was complicated by the variable light scattering due to different pellets formation.

The loss of carboxyl groups when passing from $\mathrm{H}$-Total to H-Humin, that was observed in the $1720-1710 \mathrm{~cm}^{-1}$ region, was confirmed by the clear decrease of the DRIFT absorption at around $1235 \mathrm{~cm}^{-1}$. In fact, this region is attributed to the $\mathrm{C}-\mathrm{O}$ stretching vibrations of carboxyl groups [1,21]. A decrease of this absorption region was also visible in the FTIR spectra, though less clearly than in DRIFT, because of the nearby strong absorption due to the $\mathrm{Si}-\mathrm{O}$ stretching vibration that was centered at about $1070 \mathrm{~cm}^{-1}$. This latter absorption, that covered the entire $1200-950 \mathrm{~cm}^{-1}$ region, was sensibly less broad in DRIFT spectra, thereby leaving uncovered bands which, instead, remained masked in FTIR spectra. An example was the much higher DRIFT resolution of the absorption band around $910-900 \mathrm{~cm}^{-1}$, that may be attributed to either aromatic or olephinic $\mathrm{C}-\mathrm{H}$ out-of-plane deformations [1, 21]. The region below $900 \mathrm{~cm}^{-1}$ was rather different by the two IR techniques, being slightly better resolved in FTIR for bands attributable to quartz and silicates (800, $780,695,470$, and $430 \mathrm{~cm}^{-1}$ ).

\section{Humus changes in horizons and profiles}

The DRIFT spectra of the whole soil (H-Total), and of the residues after treatments (H-Humin, B-Humin) from the three profiles, I, II, and III (Figs. 3, 2, and 4, respectively) can be used to follow the changes of humus properties through the horizons and between profiles. DRIFT spectra are used for comparison since they have been found to be superior in both resolution and sensitivity to the pellet FTIR technique.

$\mathrm{H}$-Humin residues appear to have fewer unsaturated aliphatic components than the $\mathrm{H}$-Total samples, as illustrated by the marked decrease in H-Humin samples of the $3100-3000 \mathrm{~cm}^{-1}$ region, which is commonly attributed to $\mathrm{C}-\mathrm{H}$ stretching vibrations in aromatic or olephinic double bonds [5, 12, 21-23]. Moreover, this modification varies with soil profile, the decrease of the $3100-3000 \mathrm{~cm}^{-1}$ region being in the order: profile I $>$ profile III $\geq$ profile II. These changes are accompanied by a significant increase of the bands of the aliphatic groups at 2922 and $2553 \mathrm{~cm}^{-1}$ in the H-Humin residue in all profiles, indicating that, as noted above for profile II, hydrophilic constituents of organic matter are selectively removed during the alkaline treatment of these soil samples. The intense absorption bands of aliphatic components at 2922 and $2853 \mathrm{~cm}^{-1}$ in all profiles may confirm other findings on the presence of aliphatic biopolymers such as cutan $[24,25]$ or suberan [26] in soil horizons.

Another varying feature among profiles is the flattening of the absorption around $2600-2500 \mathrm{~cm}^{-1}$ due 
to hydrogen-bonded dimers of carboxyl groups, that is noticeable in all three profiles when passing from $\mathrm{H}$-Total to H-Humin samples. However, this change, as for the decrease of the $3100-3000 \mathrm{~cm}^{-1}$ region, appeared slightly more evident in the spectra of profile I, suggesting that carboxyl groups were susceptible to a larger transformation with the alkaline treatment of this soil (Fig. 3).

The changes of the $1800-1350 \mathrm{~cm}^{-1}$ region in the residues following alkaline extraction are similar, for all three profiles, to those described above for profile II (Fig. 2). The solubilization of unsaturated carboxylic acids with soil treatment, as suggested for profile II, may also be an explanation for the changes occurring during extraction of profiles I and III (Figs. 3 and 4), based on the concomitant decrease of the two absorption bands at $1630 \mathrm{~cm}^{-1}$ (double bonds stretching in unsaturated compounds) and at around $1710-1720 \mathrm{~cm}^{-1}(\mathrm{C}=\mathrm{O}$ stretching of carboxyl groups).

However, slight variations are visible in spectra of different profiles when $\mathrm{H}$-Total samples were transformed in $\mathrm{H}$-Humin by alkaline extraction. The $1710-1720 \mathrm{~cm}^{-1}$ absorption remained much more visible in profile I (Fig. 3) followed, in the order, by profile II (Fig. 2) and III (Fig. 4), only a small shoulder being noticeable in the latter (Fig. 4). The decrease of the $1710-1720 \mathrm{~cm}^{-1}$ interval induced by the alkaline extraction was in the order: profile III $>$ profile II $>$ profile I. Another marked difference among profiles is the different unmasking of an absorption at higher wavenumbers $\left(1730 \mathrm{~cm}^{-1}\right)$ in the H-Humin residues caused by the decrease of the $\mathrm{C}=\mathrm{O}$ stretching band of $\mathrm{COOH}$ groups. This absorption band, that can be attributed to $\mathrm{C}=\mathrm{O}$ stretching of carbonyl groups in compounds less soluble in aqueous alkaline solution (see discussion in previous section), was rather sharp for profile I (Fig. 3). The fact that this band was less intense and shifted to $1720 \mathrm{~cm}^{-1}$ for profile II (Fig. 2) and just a shoulder at $1735 \mathrm{~cm}^{-1}$ in profile III (Fig. 4), is indicative of the variable chemical composition and arrangement of organic matter in the three profiles and its different resistance to solubilization in alkali.

Moreover, the band at around $1630 \mathrm{~cm}^{-1}$, attributed above to double bond stretchings in conjugated or nonconjugated unsaturated compounds, did not behave similarly in all profiles when passing from $\mathrm{H}$-Total to $\mathrm{H}$-Humin. The decrease of this absorption was slightly more evident in profile II, than in profiles I and III, thereby suggesting that there may be a different content of unsaturated compounds in the H-horizon of the profiles and/or a different solubility of these compounds in aqueous alkaline solutions. A consequence of this finding is that variable amounts of such unsaturated material may then be translocated downward in the different

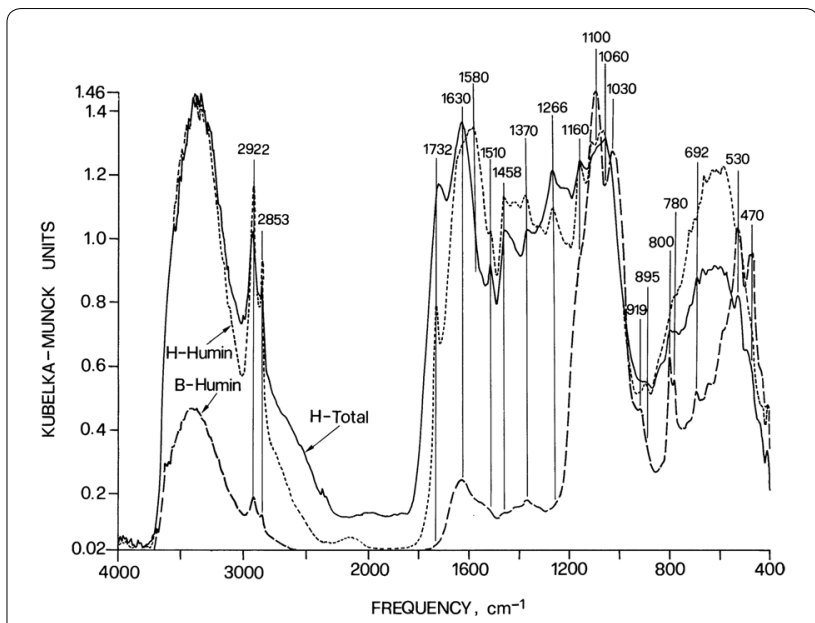

Fig. 3 DRIFT spectra of soil samples from the $H$ and $B$ horizons of profile $\mathrm{I}$. $\mathrm{H}$-Total = whole soil sample; $\mathrm{H}$-Humin = soil residue after alkaline extraction; B-Humin = soil residue after alkaline extraction. Vertical scale in Kubelka-Munk units. Spectra normalized to equal vertical scale

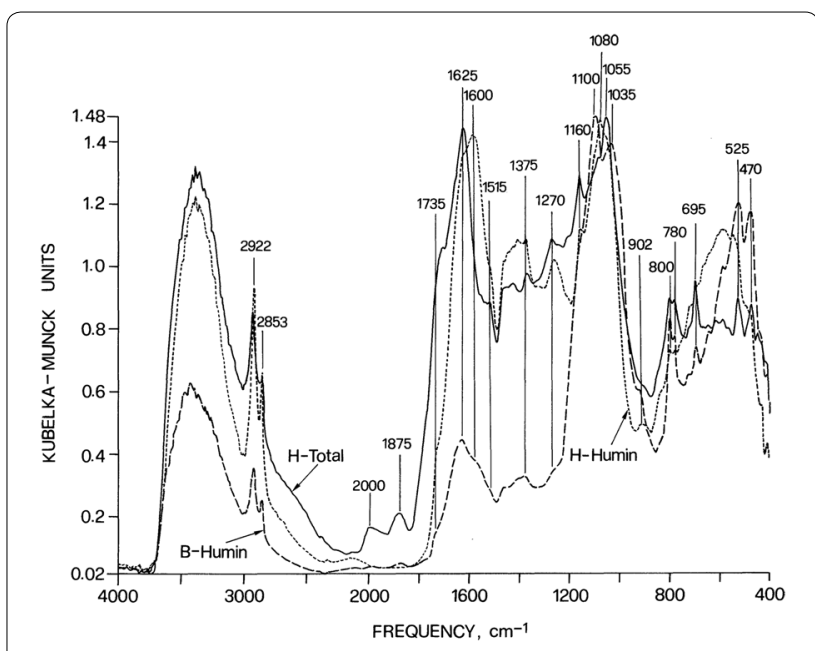

Fig. 4 DRIFT spectra of soil samples from the $\mathrm{H}$ and $\mathrm{B}$ horizons of profile III. $\mathrm{H}$-Total = whole soil sample: $\mathrm{H}$-Humin = soil residue after alkaline extraction: B-Humin = soil residue after alkaline extraction. Vertical scale in Kubelka-Munk units. Spectra normalized to equal vertical scale

profiles according to the composition of humus accumulated in the H-horizon.

Concomitant to the reduction of the $1630 \mathrm{~cm}^{-1}$ band, the absorption around $1600-1580 \mathrm{~cm}^{-1}$ due to asymmetric $\mathrm{C}=\mathrm{O}$ stretching of carboxylate groups created by the alkali treatment is not equally visible in all profiles. This absorption was centered at $1580 \mathrm{~cm}^{-1}$ in profile I, at $1595 \mathrm{~cm}^{-1}$ in profile II and at $1600 \mathrm{~cm}^{-1}$ in profile III. These observations suggest that profile I contains in the 
$\mathrm{H}$ horizon carboxyl groups which are more freely dissociable than those in profiles II and III, and, thus, the associated asymmetric carboxylate band can be centered at lower frequencies than for profiles II and III.

These findings indicate that profile I under pine forest was richer in carbonyl groups than the profiles under beech forest, the one with no undergrowth vegetation (profile III) being the poorest of all. However, another possibility may be that compounds containing carboxyl and/or carbonyl groups may have been already leached down partially (profile II) or substantially (profile III) to lower horizons. This latter explanation seems to be substantiated by the B-Humin spectra of different profiles. Profile I, which has the most visible band at $1730 \mathrm{~cm}^{-1}$ in the H-Humin sample did not show any absorption at this frequency for B-humin (Fig. 3), whereas profiles II and III which showed progressively lower intensities for the same band in the H-Humin spectra, exhibited an increasingly visible residual absorption at around $1730 \mathrm{~cm}^{-1}$ for the B-Humin samples (Figs. 2 and 4, respectively). Due to the small organic matter content, other differences among profiles are less evident for the B-Humin samples. Nevertheless, the intense bands at 2920 and $2850 \mathrm{~cm}^{-1}$ for profile III indicate that the extraction with alkali left more highly aliphatic material in the B-Humin residues of this profile than in the other two profiles and that the $1630 \mathrm{~cm}^{-1}$ band $(\mathrm{C}=\mathrm{C}$ stretching in olephinic or aromatic compounds) was rather prominent, thus suggesting a strong contribution of unsaturated compounds.

These results indicate that different type and amount of organic acids are deposited in the $\mathrm{H}$ horizons depending on vegetation, plant tissue decomposition and microbial activity. During profile development, the more water-soluble unsaturated acids are eluviated in lower B horizons, whereas the less soluble long-chain aliphatic acids or keto-acids progressively accumulate in the upper $\mathrm{H}$ horizons of the more developed profiles. However, our results also suggest that the more advanced the profile development, the larger was the accumulation of poorly watersoluble organic matter in the B horizons. This is inferred by the increase of the shoulder at $1735-1720 \mathrm{~cm}^{-1}$ (attributed to ketones in conjugated and/or heterocyclic compounds) in humin residues of the B-horizon when going from the less developed profile under pine forest to the more advanced soil profile under beech forest. Moreover, the B-humin appears richer in saturated (2920$2850 \mathrm{~cm}^{-1}$ region) and unsaturated $\left(1630 \mathrm{~cm}^{-1}\right.$ region) organic material in profile III (Fig. 4) under beech trees than in profile I (Fig. 3) under pine trees.

The presence of poorly soluble material in the lower horizons of these young soil profiles suggests that they must have been translocated in forms that are not readily available for biological degradation. These findings seem to be consistent with the supramolecular association model of humic molecules in solution [27, 28], whereby even poorly polar organic compounds may be mobilized in the soil solution provided that they are associated to the hydrophobic domains of humic aggregates. When the physical-chemical conditions of the solution vary, such as the polarity of the medium, the size of the micropores or the nature of the solid phase, the humic association may then loose its stability and some of its poorly soluble components may be deposited on the mineral surfaces. Varadachari et al. [29] have shown that the less polar the humic material, the larger is its adsorption on montmorillonite. Accumulation of such apolar organic matter in soils may be fostered by periodic drying cycles by which the less soluble compounds are adsorbed by soil mineral particles thereby forming a separate solid hydrophobic phase. Other less polar compounds may then sorb on these phases and be progressively protected from biotic degradation that can occur only in the aqueous soil solution [30, 31].

The lower content of carboxyl groups in the H-Humin residues was also the reason for the decrease in all profiles of the absorption around $1225-1235 \mathrm{~cm}^{-1}$ due to $\mathrm{C}-\mathrm{O}$ stretching in $\mathrm{COOH}$ groups. Such a decrease made more visible the band at about $1270 \mathrm{~cm}^{-1}$, that may be assigned to aliphatic skeletal vibrations $[19,21,32]$. The absorption at $1160 \mathrm{~cm}^{-1}$ may be also attributed to skeletal vibrations $[21,22]$. The intensity of the $1270 \mathrm{~cm}^{-1}$ band in the $\mathrm{H}$-Humin spectra is comparable to that in H-Total spectra for all profiles, except for a relatively enhanced sharpness due to the decrease of the $1225-1235 \mathrm{~cm}^{-1}$ region. The $1270 \mathrm{~cm}^{-1}$ absorption must then represent aliphatic groups that are less susceptible to extraction by the hydrophilic alkaline solutions and are still retained in the H-Humin soil residues in all profiles. Farmer and Morrison [33] attributed this band (together with those at around 1510, 1460 and $1420 \mathrm{~cm}^{-1}$ ) to lignins and lignin features remaining in soil organic matter. Very similar band assignments to lignin were reported elsewhere $[34,35]$. Since these bands are more visible in the $\mathrm{H}$-total and H-Humin spectra of profiles I and II than in profile III, their attribution to lignin appears consistent with the more humified character of the H-horizon of profile III where lignin transformation into humus is more advanced.

The various indications of this study that the alkaline extraction cannot entirely remove the aliphatic components of soil organic matter is in agreement with other findings that showed that humin, the unextractable fraction of soil humus, contains a large amount of aliphatic compounds such as long-chain fatty acids, long-chain alcohols, alkanes, and aliphatic biopolymers (cutin, suberin, cutan, suberan) $[18,36]$. Moreover, the persistence in soil 
of a humin fraction of mainly aliphatic character substantiates a process of soil organic matter accumulation based on the poor water solubility of the organic compounds in soils, such as phenols and fatty acids [28].

In the $1100-1000 \mathrm{~cm}^{-1}$ region of all profiles, the DRIFT spectra of B-humin revealed two distinct absorptions, centered at $1100 \mathrm{~cm}^{-1}$ and $1035 \mathrm{~cm}^{-1}$, which can be attributed to $\mathrm{Si}-\mathrm{O}$ stretching of silicate materials. Conversely, the spectra of $\mathrm{H}$-total and $\mathrm{H}$-humin samples showed neither a strong absorption in this region nor the sharp peak at $1100 \mathrm{~cm}^{-1}$ because of the smaller ash content of these samples. However, an absorption at $1060 \mathrm{~cm}^{-1}$ gained visibility after alkali treatment of soils, because silicate content became relatively larger and, possibly because carbohydrate material $(\mathrm{C}-\mathrm{O}$ stretching at around $1050-1030 \mathrm{~cm}^{-1}$ ) was lost during alkaline extraction. This behavior was particularly evident in the spectra of profile III (Fig. 4).

\section{Characteristics of humus extracts}

Supporting evidence for the described changes of soil organic matter composition following alkaline extraction can be obtained from the DRIFT spectra of the humic material extracted with $\mathrm{NaOH}$ from both the $\mathrm{H}$ and $\mathrm{B}$ horizons of the three profiles. As an example, the spectra of alkali extracts from the two horizons of profile II are shown in Fig. 5. The $\mathrm{H}-\mathrm{NaOH}$ spectrum revealed a strong band in the aliphatic region centered at $2925 \mathrm{~cm}^{-1}$, a broad absorption at around $2600 \mathrm{~cm}^{-1}$ for the $\mathrm{H}$-bonded $\mathrm{COOH}$ dimers, a notable shoulder at $1708 \mathrm{~cm}^{-1}$ for the $\mathrm{COOH}$ stretching, and an absorbing region at $1225 \mathrm{~cm}^{-1}$ for the $\mathrm{C}-\mathrm{O}$ stretching in carboxyl groups. Such IR absorptions confirm that soluble carboxylic acids of different aliphatic content were separated from the organic matter of the $\mathrm{H}$ horizon. Moreover, other soluble compounds containing hydrophilic groups such a peptide (the Amide II band at $1515 \mathrm{~cm}^{-1}$ ), alcohols (1142 and $\left.1075 \mathrm{~cm}^{-1}\right)$, and carbohydrates $\left(1045 \mathrm{~cm}^{-1}\right)$ seem to compose the alkali-extractable matter of the $\mathrm{H}$ horizon.

The extract from the $\mathrm{B}$ horizon revealed a different composition, thus reflecting the differences in organic matter composition between the $\mathrm{H}$ and the lower $\mathrm{B}$ horizons in the profile. The overall appearance of the B-NaOH spectrum (Fig. 5) suggests a lower content of aliphatic groups (only a shoulder at around $2925 \mathrm{~cm}^{-1}$ ), and a reduced absorption for the $\mathrm{CH}_{2}$ (deformation at 1450 and $1460 \mathrm{~cm}^{-1}$ ), for $\mathrm{COOH}$ functions (less absorption at about 2600, 1708 and $1225 \mathrm{~cm}^{-1}$ ), and for highly soluble compounds such as peptides, alcohols, and carbohydrates. Conversely, a large presence of carboxylate groups was apparent (the large absorptions centered at 1610 and $1400 \mathrm{~cm}^{-1}$ ), deriving, most probably, from low molecular weight carboxylic acids. Alkali solutions thus extracted from the highly mineral B horizon only the most hydrophilic components of soil organic matter, while the hydrophobic matter such as long-chain fatty acids, aromatic compounds, and biopolymers, are retained in the $\mathrm{B}-$ Humin residue.

The same differences among $\mathrm{H}$ - and $\mathrm{B}-\mathrm{NaOH}$ extracts were also evident from their FTIR spectra shown in Fig. 6, where the spectrum of the water extract from the $\mathrm{H}$ horizon is also reported. This spectrum revealed that water extracts contained weakly acidic carboxyl groups $\left(1720\right.$ and $1224 \mathrm{~cm}^{-1}$ ) which are still protonated at the $\mathrm{pH}$ of around 5.6 of the distilled water used to extract this soluble humic fractions. However, some dissociated carboxyl groups of more acidic carboxylic acids should be also present, as it is inferred by the carboxylate absorptions at around 1600 and $1400 \mathrm{~cm}^{-1}$. A comparison with a ${ }^{13} \mathrm{C}$-Cross-polarization magic-angle spinning nuclear magnetic resonance $\left({ }^{13} \mathrm{C}\right.$-CPMAS NMR) spectrum of the same sample (not shown) suggested that the very sharp and intense band may be assigned to the $\mathrm{C}-\mathrm{O}$ stretching of a specific phenolic structure. To our knowledge, no such a clear assignment of this absorption in humic extracts was previously reported in the literature.

The H-Water spectrum also shows that some aliphatic material was hydrosoluble but still containing $\mathrm{CH}_{2}$ groups (absorptions at 2820 and $2852 \mathrm{~cm}^{-1}$ ) and some unsaturated compounds. The latter are inferred from the strong absorption centered at $1633 \mathrm{~cm}^{-1}$, that is a frequency commonly assigned to double bond stretching vibrations (see above discussion). The same region in the $\mathrm{B}-\mathrm{NaOH}$ spectrum was more intense and shifted to lower frequencies $\left(1614 \mathrm{~cm}^{-1}\right)$, thereby suggesting that was due more to asymmetric stretching of carboxylate groups rather than to unsaturated material. Such interpretation is supported by the lack of absorption for $\mathrm{COOH}$ groups at around $1720-1700 \mathrm{~cm}^{-1}$, that indicates that the acids present in the extracts are in the dissociated form.

\section{Conclusions}

In this infrared study of soil residues and humus extracts from recently-developed sandy soils, DRIFT spectroscopy was shown to be superior to FTlR spectroscopy in evaluating in situ the changes in soil organic matter composition. DRIFT offered a better resolution in most of the spectral regions above $900 \mathrm{~cm}^{-1}$. The organic matter present in the $B$ horizons of these recent soils appeared to be accumulated through transport of soluble organic matter from the overlying $\mathrm{H}$ horizons. DRIFT spectra of treated and untreated soil samples are able to show that there were considerable differences in organic matter composition between the $\mathrm{H}$ and $\mathrm{B}$ horizons.

The main difference among horizons consists in the larger content of hydrophilic organic acids in the $\mathrm{H}$ 


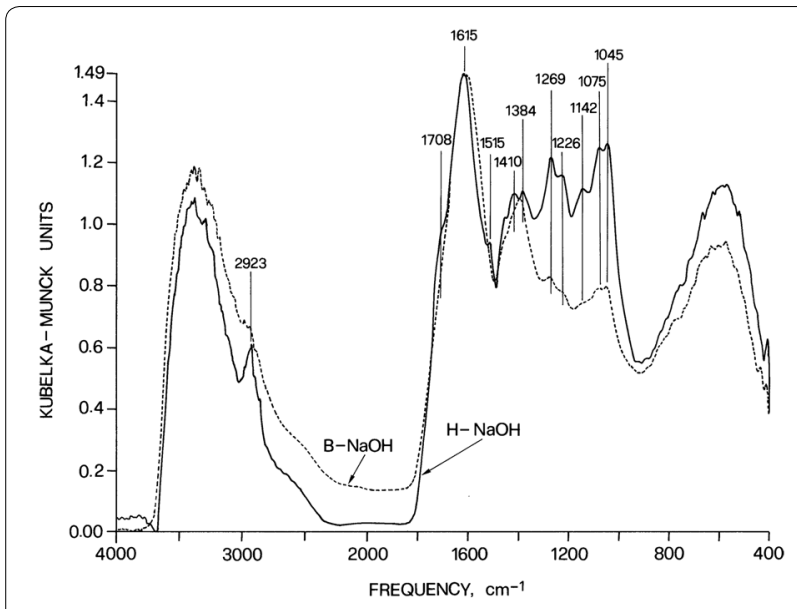

Fig. 5 DRIFT spectra of humus extracts from profile II. $\mathrm{H}-\mathrm{NaOH}=$ alkaline extract from a sample of the $\mathrm{H}$ horizon: $\mathrm{B}-\mathrm{NaOH}=$ alkaline extract from a sample of the B horizon. Vertical scale in Kubelka-Munk units. Spectra normalized to equal vertical scale

horizon extractable in aqueous alkaline solution, in comparison to B horizons. Part of the extracts was composed of unsaturated material. The humin soil residues remaining after the alkali treatment are then selectively enriched with aliphatic components, unextractable ketones, and carboxylic acids involved in physically protected complexes with minerals. These differences are observed in all profiles. In fact, the organic fractions of profiles II and III (both under beech) showed fewer carboxylic groups than those of profile I (under pine and crowberry undergrowth).

In B horizons, most of the carboxylate groups are dissociated or complexed with clay or metal ions. Since strong $\mathrm{Al}-\mathrm{O}$ and $\mathrm{Fe}-\mathrm{O}$ absorption bands were not encountered in the spectra, it seems likely that the organic matter was principally bound to the little silicate clay present in these sandy soils. The resolved bands in the silicate region of the spectra indicate that crystalline clays rather than allophane-like material were present in the samples (allophane bands were also absent below $400 \mathrm{~cm}^{-1}$ ). H-horizon water extracts showed much stronger absorption bands in the quartz and silicate region than did $\mathrm{NaOH}$ extracts from $\mathrm{H}$ and $\mathrm{B}$ horizons. This result was unexpected, because of the very low clay content of the soils. The atmospheric deposition of dust particles may be an explanation for this observation.

Infrared spectra of the organic matter left in the soil residues after $\mathrm{NaOH}$ extraction confirm previous literature findings that humin is composed to a large extent of hydrophobic aliphatic material and carboxylic functions strongly bound to minerals. This result can be explained

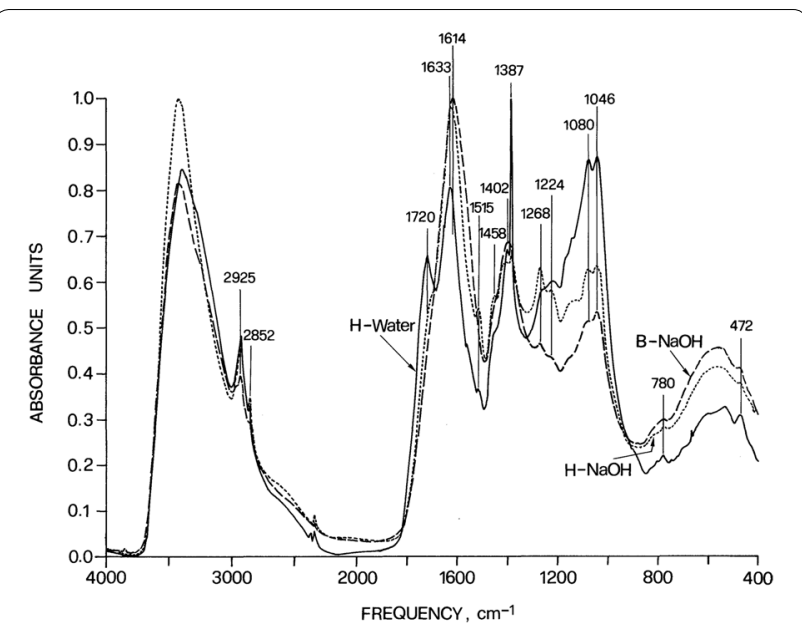

Fig. 6 FTIR spectra of humus extracts from profile II. H-Water = water extract from a sample of the $\mathrm{H}$ horizon: $\mathrm{H}-\mathrm{NaOH}=$ alkaline extract from a sample of the $\mathrm{H}$ horizon: $\mathrm{B}-\mathrm{NaOH}=$ alkaline extract from a sample of the B horizon. Vertical scale indicates absorbance. Spectra normalized to equal vertical scale

by both a humus-clay complexation mechanism through polyvalent cation bridging and a process of hydrophobic deposition, whereby the less polar components of organic matter are driven away from water and, hence, from the degrading biological activity by the adsorption on the soil mineral particles. The segregation of poorly-soluble organic compounds into the hydrophobic domains of humus associations may explain their downward transport and their presence in the B-horizons of all profiles.

Finally, this work revealed that the use of the DRIFT technique on total soil samples can become a useful tool, in terms of rapidity, cost, and easiness of instrument handling, in studies of soil organic matter dynamics in situ without the need of a preliminary extraction. In particular, DRIFT spectroscopy in combination with a systematic use of selective extractants may become a very useful tool to support the elucidation of the role played by different humus fractions on soil genetic development.

\section{Abbreviations}

FTIR: Fourier-Transformed Infrared Spectroscopy; DRIFT: Diffuse Reflectance Infrared Fourier Transform; L: litter; F: fragmentation; H: humification; E: eluvial; Bh: illuvial; KM: Kubelka-Munk; ${ }^{13} \mathrm{C}$-CPMAS NMR: ${ }^{13} \mathrm{C}$-Cross-polarization magicangle spinning nuclear magnetic resonance.

\section{Acknowledgements}

This work was partially conducted during a research visit of P. Buurman at the Dipartimento di Agraria of the University of Naples Federico II, made possible by a travel grant of the Wageningen Agriculture University, The Netherlands.

\section{Authors' contributions}

All authors have contributed equally to the work. All authors read and approved the final manuscript. 


\section{Funding}

Not applicable.

\section{Availability of data and materials}

All data generated or analysed during this study are included in this published article

\section{Ethics approval and consent to participate}

Not applicable.

\section{Consent for publication}

All authors give their personal consent for publication.

\section{Competing interests}

The authors declare that they have no competing interests.

\section{Author details}

${ }^{1}$ Centro Interdipartimentale di Ricerca sulla Risonanza, Magnetica Nucleare per I'Ambiente, I'Agro-Alimentare ed i Nuovi Materiali (CERMANU), Università di Napoli, Federico II, Via Università 100, 80055 Portici, Italy. ${ }^{2}$ Department of Soil Science and Geology, Wageningen Agricultural University, P.O. Box 37, 6700 AA Wageningen, The Netherlands. ${ }^{3}$ Dipartimento di Agraria, Università di Napoli Federico II, Via Università 100, 80055 Portici, Italy.

\section{Received: 11 October 2019 Accepted: 23 November 2019}

Published online: 19 March 2020

\section{References}

1. Stevenson FJ. Humus chemistry genesis, composition, reactions. New York: Wiley; 1994.

2. Buurman P. The use of physico-chemical methods of analysis. In: Buurman P, editor. Decomposition and accumulation of organic matter in terrestrial ecosystems: research Priorities and approaches, vol. 12. Brussels: Ecosystem Research Report CEC; 1994. p. 13-4.

3. Piccolo A. In memoriam Prof. F.J. Stevenson and the question of humic substances in soil. Chem Biol Technol Agric. 2016;3:23.

4. Van Breemen N, Heal OW. Decomposition and accumulation of organic matter in terrestrial ecosystems: a key process in biogeochernistry and environmental change. In: van Breemen $\mathrm{N}$, editor. Decomposition and accumulation of organic matter in terrestrial ecosystems: research Priorities and approaches. Brussels: Ecosystem Research Report CEC; 1991. p. $1-5$.

5. Piccolo A, Stevenson FJ. Infrared spectroscopy evidence of thermal decarboxylation in potassium salts of humic substances. In: Senesi N, Miano TM, editors. Humic substances in the global environment and implications on Human Health. Elsevier: Amsterdam; 1994. p. 329-34.

6. Baes AU, Bloom PR. Diffuse Reflectance and transmission Fourier Transform Infrared (DRIFT) spectroscopy of humic and fulvic acids. Soil Sci Soc Am J. 1989;53:695-700.

7. Nguyen TT, Janik $L$, Raupach M. Diffuse reflectance Infrared Fourier Transfom1 (DRIFT) Spectroscopy in soil studies. Aust J Soil Res. 1991;29:49-67.

8. Niemeyer J, Chen T, Bollag JM. Characterization of hurnic acids. cornposts, and peat by diffuse reflectance Fourier-Transform infrared spectroscopy. Soil Sci Soc Am J. 1992;56:135-40.

9. Tremblay L, Gagné J-P. Distribution and biogeochemistry of sedimentary humic substances in the St. Lawrence Estuary and the Saguenay Fjord. Québec. Org Geochem. 2007;38:682-99.

10. Matamala R, Calderón FJ, Jastrow JD, Fan ZS, Hofmann SM, Michaelson GJ, Mishra U, Ping C-L. Influence of site and soil properties on the DRIFT spectra of northern cold-region soils. Geoderma. 2017;305:80-91.

11. Parker RW, Frost RL. The application of DRIFT spectroscopy to the multicomponent analysis of organic chemicals adsorbed on montmorillonite. Clays Clay Minerals. 1996;44:32-40.

12. Spaccini R, Piccolo A, Haberhauer G, Stemmer M, Gerzabek MH. Decomposition of maize straw in different European soils as revealed by DRIFT spectra of soil particle fractions. Geoderma. 2001;99:245-60.

13. Fanta J. Primary forest succession on blown-out areas in tbc dutch drift sands. In: Fanta J, editor. Forest Dynamics research in Western and Central
Europe. Proc. Workshop Wageningen, 17-20 Sep. 1985. PUDOC, Wageningen. 1986; p. 164-169.

14. Prach K. Primary forest succession in sand dune areas. The Veluwe, Central Netherlands. 'De Dorschkamp' Research Institute for Forestry and Landscape Planning, Wageningen, Report 544; 1989, p 117.

15. Green RN, Towbridge RL, Klinka K. Towards a taxonomic classification of humus forms Society of American Foresters. Forest Science Monograph. 1993;29:1-49.

16. FAO. Guidelines for soil description. Rome: FAO; 1990.

17. Munsell Color. Munsell Soil Color Charts. Baltimore: Kollmorgen Corp; 1975.

18. Nebbioso A, Vinci G, Drosos M, Spaccini R, Piccolo A. Unveiling the molecular composition of the unextractable soil organic fraction (humin) by humeomics. Biol Fert Soils. 2015;51:443-51.

19. Piccolo A, Stevenson FJ. Infrared spectra of $\mathrm{Cu}^{2+}, \mathrm{Pb}^{2+}$, and $\mathrm{Ca}^{2+} \mathrm{com}-$ plexes of soil humic substances. Geoderma. 1982;27:195-208.

20. Farmer VC, Palmieri F. The characterization of soil minerals by infrared spectroscopy. In: Gieseking JE, editor. Soil components, vol. II. Springer: New York; 1975. p. 573-670.

21. Bellamy LJ. The infrared spectra of complex molecules. London: Chapman \& Hall; 1975. p. 1-433.

22. Williams DJ-I, Fleming I. Spectroscopic methods in organic chemistry. London: McGraw-Hill; 1995. p. 28-62.

23. Piccolo A, Rausa R, Celano G. Molecular weight distribution of humic substances from an oxidized coal and their ultrafiltered fractions. Chemosphere. 1992;24:1381-7

24. Nip M, Tegelaar EW, De Leeuw JM, Schenck PA, Holloway PJ. A new nonsaponifiable highly aliphatic and resistant biopolymer in plant cuticules: evidence from pyrolysis and ${ }^{13} \mathrm{C}-\mathrm{NMR}$ analysis of present day and fossil plants. Naturwissenschaften. 1986;73:579-85.

25. Nip M, De Leeuw JW, Holloway PJ, Jensen JPT, Spenkels JCM, Poorter M, Sleeks JJM. Comparison of flash pyrolysis, differential scanning calorimetry, ${ }^{13} \mathrm{C}$ NMR and IR spectroscopy in the analysis of a highly aliphatic biolpolymer from plant cuticles. J Anal Appl Pyrol. 1987;11:287-95.

26. Tegelaar EW, Hollman G, Van der Vegt P, De Leeuw JW, Holloway PJ. Chemical characterization of the periderm tissue of some angiosperm species: recognition of an insoluble, non-hydrolysable, aliphatic macromolecule (suberan). Org Geochem. 1995;23:234-50.

27. Piccolo A. The supramolecular structure of humic substances. A novel understanding of humus chemistry and implications in soil science. Adv Agronom. 2002;75:57-134.

28. Piccolo A, Spaccini R, Savy D, Drosos M, Cozzolino V. The soil humeome: chemical structure, functions and technological perspectives. In: Vaz Jr. S, editor. Sustainable agrochemistry: a compendium of technologies. Heidelberg: Springer Nature; 2019. p. 183-222.

29. Varadachari C, Monda AH, Nayak DC, Ghosh K. Some aspects of clayhumus complexation: effect of exchangeable cations on lattice charge. Soil Sci. 1991;15:220-7.

30. Drosos M, Piccolo A. The molecular dynamics of soil humus as a function of tillage. Land Degr. Develop. 2018;29:1792-805. https://doi. org/10.1002/ldr.2989.

31. Piccolo A. Humus and soil conservation. In: Piccolo A, editor. Humic substances in terrestrial ecosystems. Amsterdam: Elsevier; 1996. p. 225-64.

32. Stevenson FJ, Goh KM. Infrared spectra of humic acids and related substances. Geochim Cosmochim Acta. 1971;35:471-83.

33. Farmer VC, Morrison RI. Lignin in sphagnum and phragmites and in peats derived from these plants. Geochim Cosmochim Acta. 1964:28:1537-46.

34. Savy D, Nebbioso A, Mazzei P, Drosos M, Piccolo A. Molecular composition of water-soluble lignins separated from different non-food biomasses. Fuel Proces Technol. 2015;131:175-81.

35. Van der Marel HW, Beutelspacher H. Atlas of infrared spectroscopy of clay minerals and their admixtures. Amsterdam etc.: Elsevier; 1976.

36. Saiz-Jimenez C. The chemical structure of humic substances: recent advances. In: Piccolo A, editor. Humic Substances in Terrestrial Ecosystems. Elsevier: Amsterdam; 1996. p. 1-44.

\section{Publisher's Note}

Springer Nature remains neutral with regard to jurisdictional claims in published maps and institutional affiliations. 